\title{
Travma sonucu santral dişlerde gelişen ekstrüzyon yaralanması ve tedavisi: Olgu sunumu
}

\author{
Nazlı Özge Yanar ${ }^{1}$ \\ Selcuk Dental Journal, 2014; 3: 129-133
}

\section{Treatment of traumatized central teeth with extrusion: A case report}

Dentoalveolar traumas often develop depending on various traumas such as fights, fallings, traffic accidents, sports injuries and game accidents. Dentoalveolar injuries may result from directly or indirectly trauma to the teeth. These cases are usually accompanied by soft tissue injuries around the mouth. Traumatic injuries of permanent teeth is usually reported to happen to children and young adults and most commonly occur in the upper incisors. In these cases, it is intended to maintain the optimum function, phonation and aesthetic of the tooth. An accurate diagnosis , treatment planning and follow-up; is important to obtain a therapeutic result.

\section{KEY WORDS}

Dental trauma, extrusion, root canal treatment

Diş hekimliğinde dental travma vakalarının büyük çoğunluğu çocukluk döneminde bisiklet kazalarında, spor etkinlikleri sırasında veya düşme sonucunda ortaya çıkmaktadır. Travma sonucu meydana gelen yaralanmalar ön grup dişlerde diğerlerine göre daha fazla görülmekte ve çürükten sonra acil dental problemlerin başında gelmektedir (Alaçam 2012, Baratieri ve ark. 1990, Uz ve Uz 1990). Daimi dişlerde görülen dental travmaların \%1561'ini, süt dişlerinin ise \%62-73'ünü oluşturan lüksasyon tarzı travmatik yaralanmalar, tedavi ve iyileşme şekli açısından bakıldığında sarsıntı, sublüksasyon, ekstrüzyon, lateral lüksasyon ve intrüzyon olarak beş gruba ayrılmaktadır (Andreasen ve ark. 2002).

Travmatik dental yaralanmalar, çocuk ve genç erişkinlerde büyük sıklıkla gerçekleşmekte olup, insanlarda tedavi intiyacı gerektiren tüm yaralanmaların \%5'ini oluşturmaktadır (Petersson ve ark.1997, Andreasen ve ark. 2007). 12 yıllık bir literatür incelemesinde, tüm okul dönemi çocuklarının \%25'inin bir diş yaralanması geçirdiği, erişkinlerin \%33'ünün ise çoğunun 19 yaş öncesinde olmak üzere kalıcı dişlerinde travmaya maruz kaldığı rapor edilmiştir (Glendor 2008). Süt dişlenmede lüksasyon yaralanmaları en sık rastlanan travmatik dental yaralanmalar iken, kalıcı dişlerde kron kırıkları daha sıklıkla rapor edilmektedir (Andreasen ve ark. 2007, Flores 2002, Kramer ve ark. 2003). Travmatik dental yaralanmalar, tüm hekimler açısından güç bir durumdur. Dolayısıyla, doğru bir teşhis, tedavi planlaması ve takip; olumlu bir tedavi sonucunun kesinleştirilebilmesi yönünden kritik önem taşımaktadır. Travmatik yaralanmaların en sık üst kesici dişlerde ortaya çıktığı bildirilmiştir (Alaçam 2012). Bu tip travmatik vakalarda dişin çekilmeden sağılıkı bir çiğneme yapması, iyi bir estetik görünüm sağlaması ve konuşmadaki fonksiyonları açısından ağızda devamlı̆̆ğ istenir. Burada travma sonucu santral dişlerde meydana gelen ekstrüziv lüksasyon vakası, tedavisi ve bir yıllık tedavi sonuçları gösterilen bir olgu sunulmuştur.

\section{OLGU}

16 yaşındaki bayan hasta, 10-12 saat önce banyoda düşüp çenesini lavaboya çarpması sonucu üst çene santral dişlerde sallanma ve ağrı şikayetiyle kliniğimize başvurdu. Alınan anamnez sonucunda hastanın herhangi bir sistemik hastalığı olmadığı öğrenildi. Hastanın ağız dışı, ağız içi ve radyografik muayenelerinde; yumuşak dokuda hemoraji ve yaralanmalar olduğu, dudaklarda şişlikler meydana geldiği, alveol kemiğinde ve dişlerin kron ve köklerinde kırık olmadığı, ancak üst çene santral dişlerde meydana gelen ekstrüzyon sebebiyle, dişlerin uzamış olduğu ve mobilitenin aşırı derecede arttığı ve dişin

\footnotetext{
${ }^{1}$ Batman Kadın-Doğum Hastanesi Diş Polikliniği Endodonti Uzmanı, Batman, Türkiye
} 
apikalinde genişlemiş peridontal ligament aralığı varlığı gözlendi (Resim 1, Resim 2). Dişlerin orijinal pozisyonuna getirilip splintlenmesi ve kanal tedavisini içeren bir tedavi planlaması yapıldı. Dişler orijinal konumlarına getirilerek $0.9 \mathrm{~mm}$ çapında yarı esnek bir splint, ışıkla sertleşen kompozit rezin kullanılarak kanin-kanin arası bölgeye uygulandı. Aynı seans kanal tedavisine başlandı. Kök kanalları kanal boyu tespitinden sonra çalışma boyunda, el eğeleri ile \#80 nolu eğe boyutuna kadar genişletildi. İrigasyon ajanı olarak her alet sonrasında 2,5 ml \% 2,5'lik NaOCl kullanıldı. Sonrasında $3 \mathrm{ml}$ \%5 EDTA (Wizard, Türkiye) ile yıkama yapıldı. EDTA artıklarını kanaldan uzaklaştırmak için Serum Fizyolojik solüsyon ile yıkama yapıldı. Kanallar kağıt konlarla (DiaDent, Kore) kurutuldu. Kök kanalları kalsiyum hidroksit $(\mathrm{Ca}(\mathrm{OH}) 2)$ ile doldurulduktan sonra 1 hafta beklendi ve sonraki seansta kök kanalları $\mathrm{AH}$ 26 (Dentsply, DeTrey, Germany) ve gutta perka kullanılarak lateral kondensasyon yöntemi ile dolduruldu. İki haftalık splintleme süresi sonunda dişlerdeki mobilitenin azaldığı izlendi (Resim 3, Resim 4). Hasta 1 ay sonra kontrol seansına davet edildi. Bir yıl sonraki kontrollerinde yapılan ağız dışı, ağız içi ve radyografik muayeneler sonucunda; dişlerin asemptomatik olduğu, periodonsiyumun klinik ve radyografik olarak normal olduğu ve uyumlu bir marjinal kemik yüksekliği olduğu tespit edildi (Resim 5, Resim 6). Hasta dişlerin estetik ve fonksiyonundan memnun olduğunu belirtti.

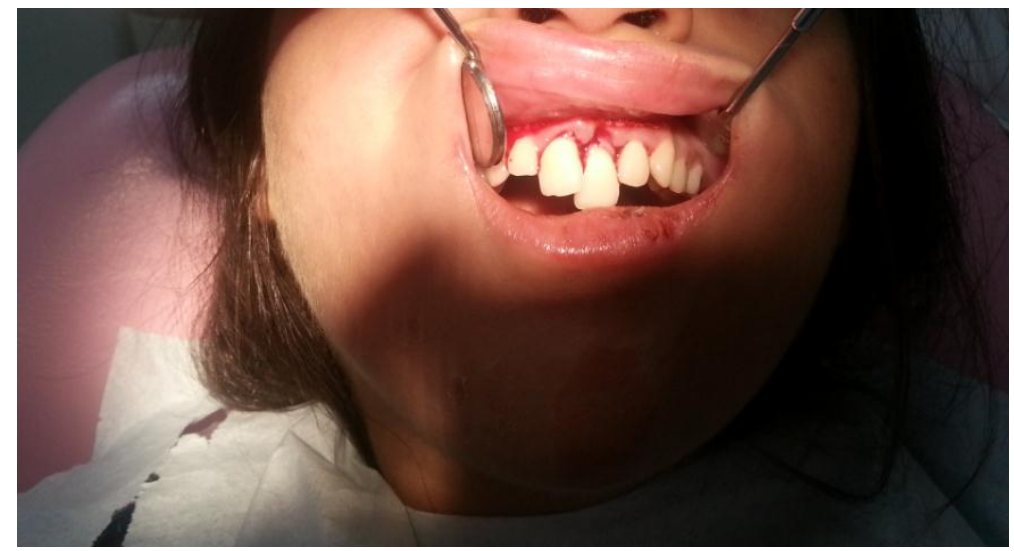

Resim 1.

Hastanın travma sonrası ağız içi ve ağız çevresi yumuşak doku görüntüsü

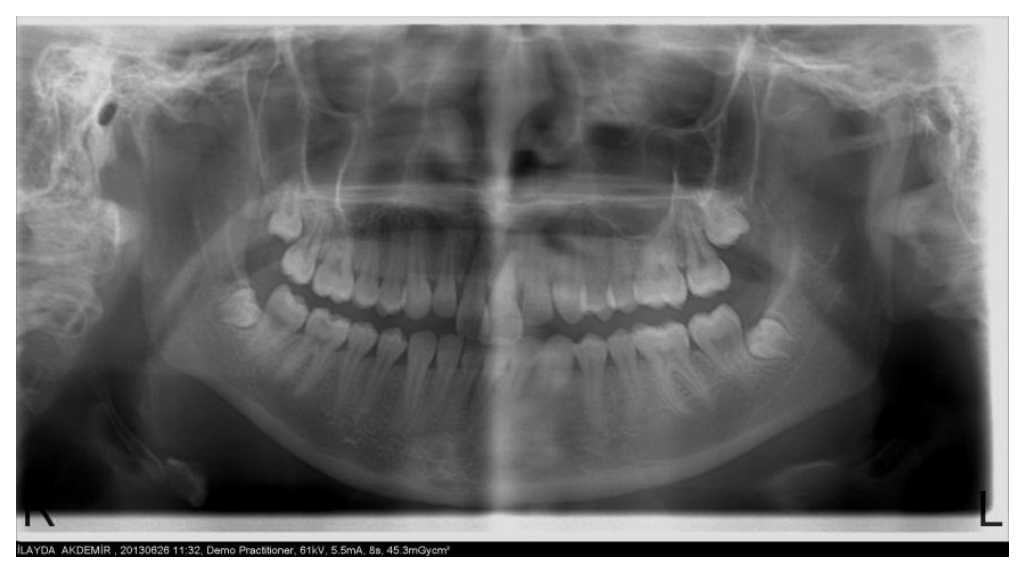

Resim 2.

Travma sonrası radyografik görünüm
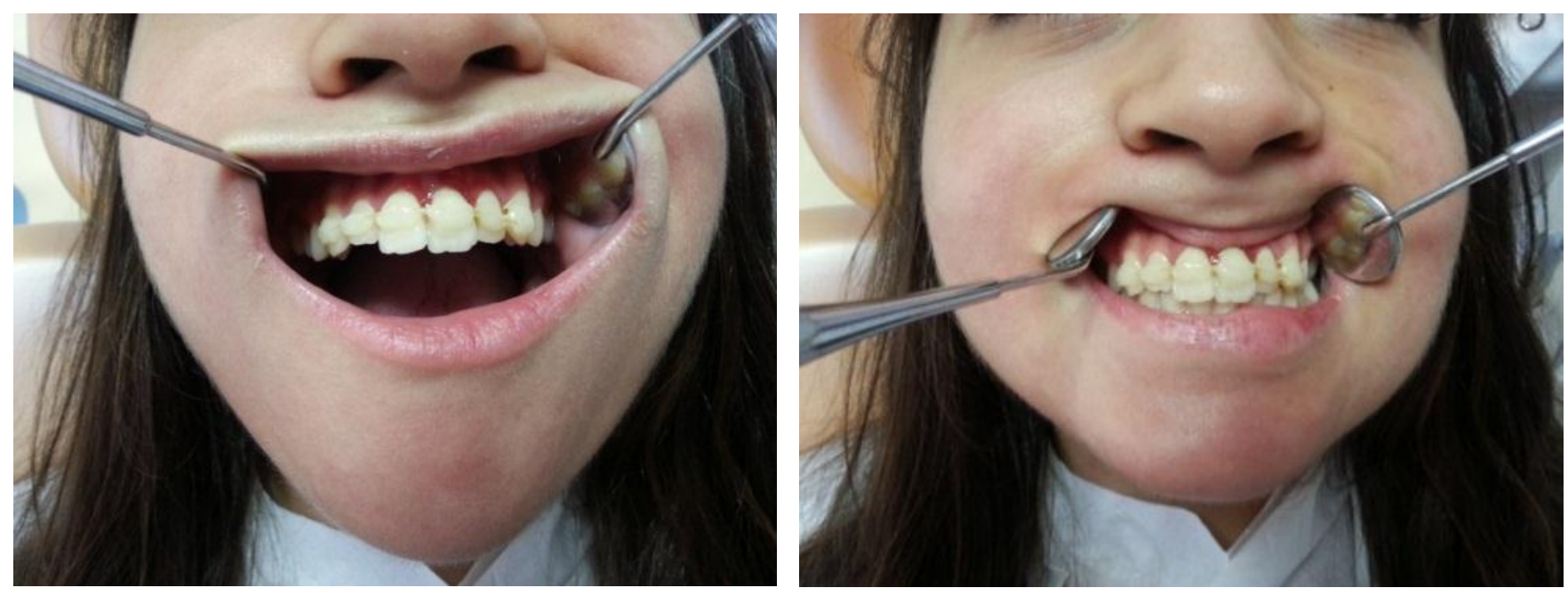

Resim 3.

2 haftalık splint tedavisi sonrası görünüm 


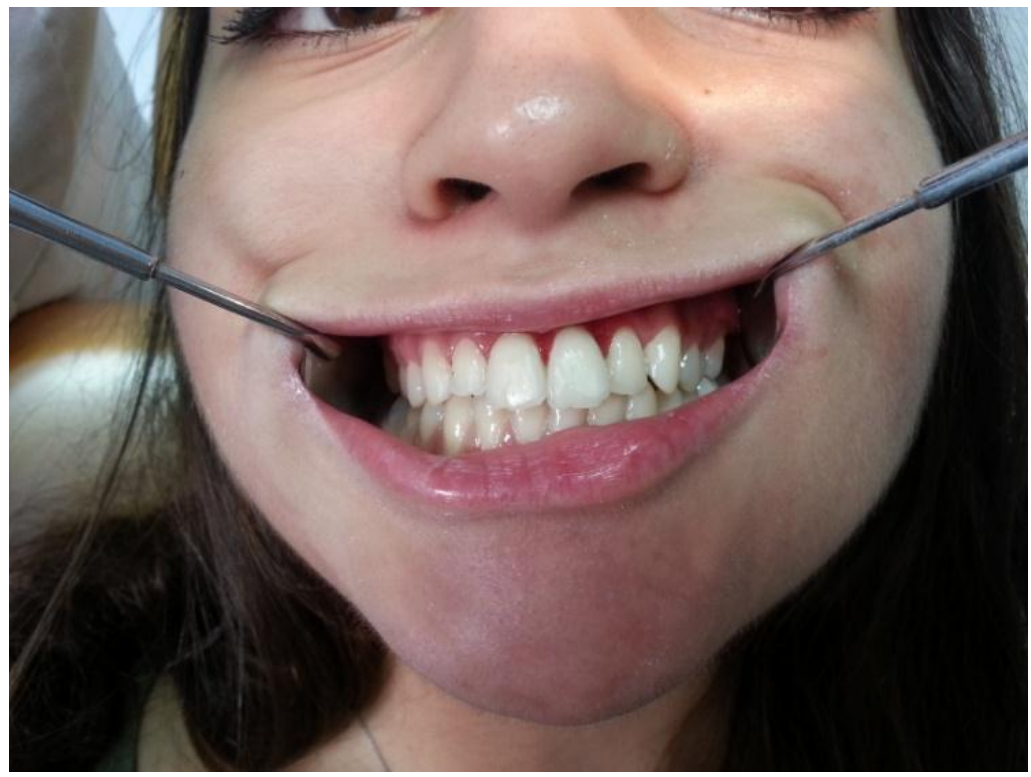

Resim 4.

Splint çıkarıldıktan sonra dişlerin görünümü

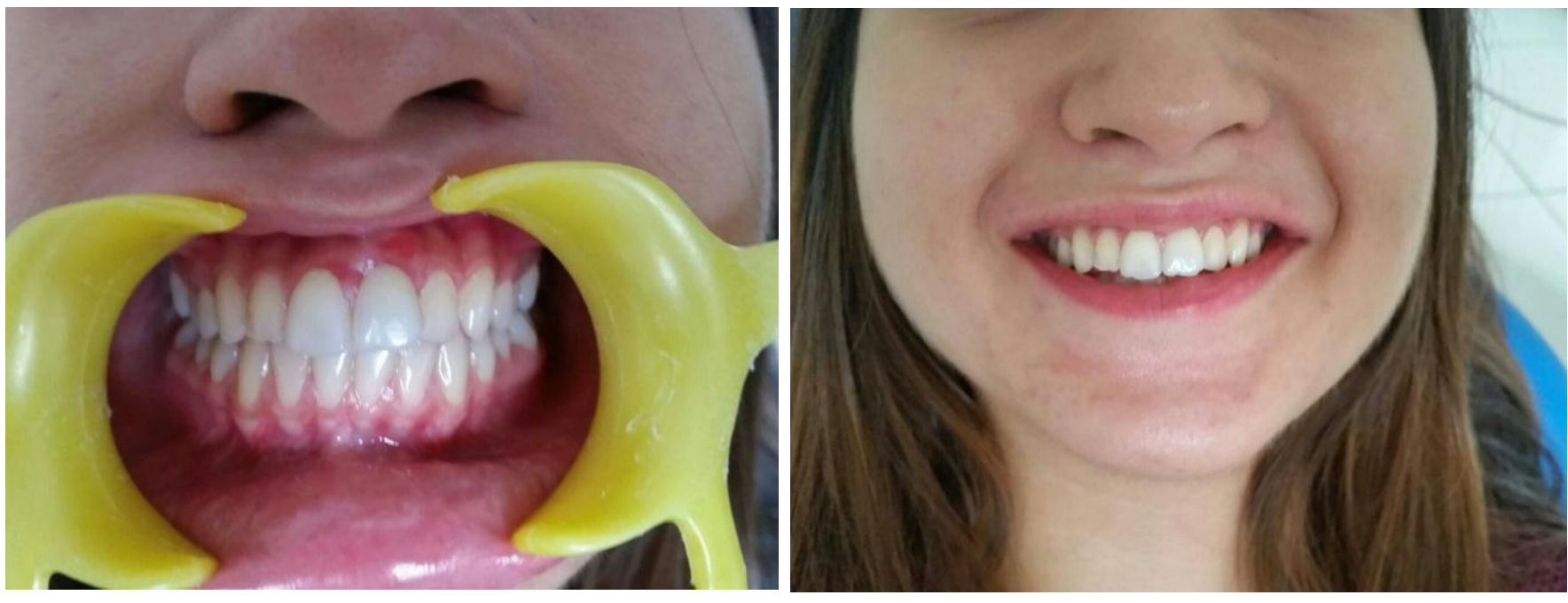

Resim 5.

Tedavi sonrası birinci yıl ağız içi görünümü

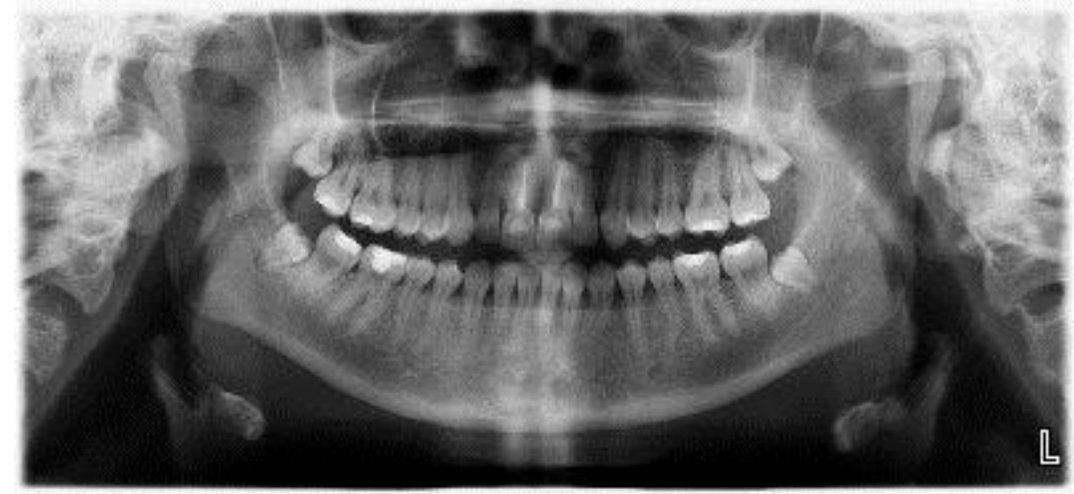

Resim 6.

Tedaviden 1 yıl sonra radyografik görünüm 


\section{TARTISSMA}

Dental travmalar incelendiğinde, üst kesici dişlerin, arktaki pozisyonlarından dolayı travmaya en çok maruz kalan diş grubu olduğu ve bu durumun genellikle kuronda ciddi madde kaybıyla sonuçlandığı bilinmektedir (Schillingburg ve ark. 1997, Petti ve Tarsitani 1996, Leroy ve ark. 2000). Sunulan bu vakada, kronda herhangi bir harabiyet olmaması tedavinin prognozunu olumlu yönde etkilemiştir. Dental yaralanmalar, travmanın şiddetine göre bazen ağız ve çevresindeki yumuşak dokular ve dişlerde hafif bir etkiye neden olurken, genellikle hastaları ağrı, fonksiyon, estetik ve psikolojik olarak birçok yönden olumsuz etkileyen ciddi bir problemdir. Çene yüz bölgesine gelen travmanın şiddeti, çarpan cismin elastikliği, şekli, geliş yönü, dudakların ve diğer yumuşak dokuların bu kuvveti ne derece azalttığı, diş ve çene yapısının sağlamlığı dentoalveolar yaralanmalarda oluşabilecek hasarı belirleyen ana unsurlardır (Özel ve Altundal 2006).

Travma sonucunda yer değiştiren dişlerin restore edilmesinde en önemli sorun primer stabilizasyondur. $\mathrm{Bu}$ amaçla diş çiğneme fonksiyonundan uzaklaştırlır ve komşu dişlere splintlenerek sabitlenir (Çetin ve Özcan 2013). Anterior bölgeye gelen travmalar acil müdahale gerektiren durumlardır. Travmaya sebep olan etkenin özelliklerinin yanında, hastanın yaşı ve travmanın geldiği bölge de önem teşkil etmektedir. Travmanın türüne ve pulpanın durumuna göre kanal tedavisi, kuafaj, koronal amputasyon seçenekleri değerlendirilir. Travma nedeniyle etkilenen daimi diş, hasta açısından neden olabileceği fonksiyonel bozuklukların yanı sıra özellikle genç hastalarda estetik açıdan da büyük bir problem olarak nitelendirilmektedir. Andreasen yaptığı çalışmada ciddi travmatik dental yaralanmalar neticesinde komplikasyonların 5-10 sene içerisinde bile ortaya çıkabileceğini bildirmiş ve travmaya uğrayan dişlerin düzenli bir şekilde takibini önermiştir (Andreasen 1989). Çalışmamızda, travma sonucu ekstrüzyona uğramış üst çene santral dişlerin orijinal pozisyonlarında splintlenmesi ile bir yıllık takip periyodu sonucunda izlenen klinik başarı ve estetik sonuçlar gösterilmiştir.

\section{SONUÇ}

Daimi dişlerde rastlanılan lüksasyon tarzındaki dental yaralanmaların erken dönemde teşhisi, doğru tedavi prosedürünün uygulanması ve ortaya çıkabilecek muhtemel komplikasyonlar açısından uzun süreli klinik ve radyolojik takibi önemlidir.
Kontrol seansları, hasta uyumu, titiz bir ağız bakımı ve travmaya sebep olabilecek faktörlerden kaçınması ile daha ileri yaralanmaların önlenmesi travmatik dental yaralanma sonrasında iyileşmeye önemli katkı sağlamaktadır. Bu olguda olduğu gibi santral dişlerde travma sonucu meydana gelen ektrüziv lüksasyon yaralanmaları uygun tedavi planı ile çekime gerek kalmaksızın başarı ile tedavi edilebilirler.

Travma sonucu santral dişlerde gelişen ekstrüzyon yaralanması ve tedavisi: Olgu sunumu

Kavga, düşme, trafik kazası, spor yaralanmaları ve oyun kazaları gibi çeşitli travmalara bağlı olarak sıklıkla dentoalveolar yaralanmalar gelişir. Dentoalveolar yaralanmalar, ya doğrudan dişlere gelen travma sonucu ya da dolaylı olarak meydana gelebilir. Bu vakalara genellikle ağız çevresi yumuşak doku yaralanmaları da eşlik eder. Daimi dişlerin travmatik yaralanmaları, genellikle çocuk ve genç erişkinlerde görülmekte ve en sık olarak üst kesici dişlerde ortaya çıktığı bildirilmektedir. Bu vakalarda dişin çekilmeden sağlıklı bir fonksiyon, fonasyon ve estetik sağlayarak ağızda devamlı̆ı̆ı istenir. Doğru bir teşhis, tedavi planlaması ve takip; olumlu bir tedavi sonucu elde edilmesi açısından önemlidir.

\section{ANAHTAR KELIMELER}

Dental travma, ekstrüzyon, kök kanal tedavisi

\section{KAYNAKLAR}

Alaçam T, 2012. Travma Nedeniyle Oluşan Diş Yaralanmaları Ve Tedavileri, In: Endodonti, Ed; Alaçam T, Özyurt Matbaacılık, Ankara, pp; 9851058.

Andreasen FM, 1989. Pulpal healing after luxation injuries and root fracture in the permanent dentition. Endod Dent Traumatol, 5, 111-131.

Andreasen JO, Andreasen FM, Skeie A, HjørtingHansen E, Schwartz O, 2002. Effect of treatment delay upon pulp and periodontal healing of traumatic dental injuries - a review article. Dent Traumatol, 18, 116-128. 
Andreasen JO, Andreasen FM, Andersson L, 2007. Textbook and color atlas of traumatic injuries to the teeth, 4th edn. Oxford, UK: Wiley-Blackwell.

Baratieri, LN, Monterira, S, De Andrade, MAC, 1990. Tooth fracture reattachment: case report. Quintessence International,21, 261-270.

Çetin AR, Özcan E, 2013. Travma geçirmiş anterior dişlerde gelişen kök kırıklarında restoratif tedavi yaklaşımı (üç olgu nedeniyle). S.D.Ü Sağlık Bilimleri Enstitusu Dergisi, 4, 3,125-129.

Flores MT, 2002. Traumatic injuries in the primary dentition. Dent Traumatol, 18,287-298.

Glendor U, 2008. Epidemiology of traumatic dental injuries - a 12 year review of the literature. Dent Traumatol, 24, 603-611.

Kramer PF, Zembruski C, Ferreira SH, Feldens CA, 2003. Traumatic dental injuries in Brazilian preschool children. Dent Traumatol, 19,299-303.

Leroy RL, Aps JK, Raes FM, Martens LC, De Boever $\mathrm{JA}, 2000$. A multidisciplinary treatment aproach to a complicated ma $\neg$ xillary dental trauma: a case report. Endod Dent Traumatol,16,138-142.

Özel E, Altundal H, Dentoalveolar ve perioral yumuşak doku yaralanmaları, 2006, Atatürk Üniv Diş Hek Fak Derg, 4, 7-13.

Petersson EE, Andersson L, Sorensen S, 1997. Traumatic oral vs nonoral injuries, Swed Dent J, 21,55-68.

Petti S, Tarsitani G, 1996. Traumatic injuries to anterior teeth in Ita $\neg$ lian schoolchildren: prevalence and risk factors, Endod Dent Traumatol, 12,294-297.

Schillingburg HT, Hobo S, Whitsett LD, Jacobi R, Brackett S, 1997. Fundamentals of fixed prosthodontics, 3rd edn. IL: Quintessence Publishing, pp; 197-201.

Uz Z, Uz H, 1990. Ön diş travmaları, D.Ü. Diş Hek Fak Dergisi, 1 (3), 176-180.

Yazışma Adresi:

Dr.Dt.Nazlı Özge Yanar

Batman Kadın Doğum ve Çocuk Hastalıkları Hastanesi

Ziya Gökalp Mah. Ssk Caddesi, Batman

E-mail: ozgeyanar@hotmail.com 